\title{
A 32-year demography of yellow-bellied marmots (Marmota flaviventris)
}

\author{
Orlando A. Schwartz ${ }^{1}$, Kenneth B. Armitage ${ }^{2 *}$ and Dirk Van Vuren ${ }^{3}$ \\ ${ }^{1}$ Department of Biology, University of Northern Iowa, Cedar Falls, IA 50614-0421, U.S.A. \\ ${ }^{2}$ Department of Systematics and Ecology, University of Kansas, Lawrence, KS 66045-2106, U.S.A. \\ ${ }^{3}$ Department of Wildlife, Fish, and Conservation Biology, University of California, Davis, CA 95616, U.S.A. \\ (Accepted 7 May 1998)
}

\begin{abstract}
Yellow-bellied marmots Marmota flaviventris in the East River Valley of Colorado were live-trapped and individually marked annually from 1962 through 1993. These pooled data were used to produce a demography and life table for these years. Females had significantly better survivorship than males beyond the first-year age class, and the sex ratio became progressively female biased. The major mortality factors of predation and unsuccessful hibernation acted evenly on all age classes as shown by the constant rates of survivorship. The rate of senescence indicated that the probability of mortality did not increase with age. Females produced litters from ages 2 to 10 years. Mean litter size was 4.1 and did not differ among age classes. The female generation length of 4.49 years was 2.4 times the life expectancy and the median survivorship. The net reproductive rate $\left(R_{\mathrm{o}}\right)$ was 0.67 , yet the population did not continually decline; adjustments to these data increased $R_{\mathrm{o}}$ to 0.85 . Reproductive values $\left(V_{\mathrm{x}}\right)$ were approximately equal across the reproductive age classes. The polygynous mating system is both cause and effect of the demography. Marmot population size is affected by weather factors that influence reproduction and survival, by predation, and by movement into and out of the study area.
\end{abstract}

Key words: yellow-bellied marmot, demography, life table, sex ratio, Marmota flaviventris

\section{INTRODUCTION}

Demographic data are important for the study of vertebrate populations because such data form the basis for management and conservation of a species and provide information needed to evaluate the effect of climate change: e.g. do demographic changes reflect short-term fluctuation or long-term trends (Van Horne et al., 1997)? Demographic data are necessary to test life-history theory: e.g. is there a trade-off between current and future reproduction, does reproductive value vary among age classes (Stearns, 1992), does senescence occur (Promislow, 1991) and do females have greater longevity than males (D. W. E. Smith, 1989)? In addition, demographic data are needed to explore possible relationships between demographic patterns and social systems (Armitage, 1996). Demographic data were used to calculate an index of social complexity, but this comparative analysis was hampered

\footnotetext{
*All correspondence to: Kenneth B. Armitage, Department of Systematics and Ecology, The University of Kansas, Lawrence, KS 66045-2106, U.S.A. E-mail: mamots@lark.cc.ukans.edu
}

by the lack of demographic data (Blumstein \& Armitage, 1997).

A previous 11-year demography (1962-1972) of the yellow-bellied marmot Marmota flaviventris (Armitage \& Downhower, 1974) had three major shortcomings. First, the time period was shorter than the lifespan of this species. Second, there was little information on the fate of dispersers. Because most males disperse as yearlings (Armitage, 1974), a life table for males was not possible at that time. Third, because reproduction and mortality vary widely from year to year (Schwartz \& Armitage, in press $a$ ), a longer time period is necessary in order to obtain satisfactory life tables for males and females.

Thus, we report a cohort-specific demography for yellow-bellied marmots based on 1532 known-age individuals trapped between 1962 and 1993 . We present standard life-table statistics for males and females and discuss the factors likely to affect the patterns of reproduction and survival revealed by the life tables. In addition, we compare this study with the previous 11-year demography to demonstrate the importance of long-term research. Finally, we relate demographic patterns to social systems in ground-dwelling scuirids. 


\section{METHODS}

\section{Natural history}

We studied yellow-bellied marmots in Transition zone habitat at $2900 \mathrm{~m}$ in the upper East River Valley of Gunnison County, Colorado. Marmots occupied an extensive but discontinuous grassland similar to the Festuca thurberi community type described by Langenheim (1962), but dominated by several species of Bromus and Poa and with an abundance of large, showy forbs (Kilgore \& Armitage, 1978). The grassland was interspersed with stands of spruce Picea engelmanni, quaking aspen Populus tremuloides, and willow Salix. Marmots typically occupied meadows associated with talus or large boulders, where they built their burrow systems (Svendsen, 1974). These habitats formed a continuum of sizes ranging from satellite areas as small as 0.01 ha occupied typically by an adult female, her litter, and sometimes an adult male, to colony areas as large as 7.2 ha occupied by one or more polygynous social groups that each typically consisted of 1 male, 2 or more adult females, yearlings (marmots 1-year old), and young (Armitage, 1991). Marmots produced a single litter per year of 1 to 8 young that typically appeared above ground in late June or early July. Most young marmots remained and hibernated at their natal site; most dispersal was by yearlings.

\section{Trapping}

Each year marmots living in the study sites (Armitage, 1974; Svendsen, 1974, for descriptions) were livetrapped and their sex, mass, age, and reproductive status noted. Young, yearlings, and 2-year olds were readily aged by body mass (Armitage, Downhower \& Svendsen, 1976). Typically, trapping was carried out from mid-May until mid-August. At first capture each animal received a pair of numbered ear tags and all marmots received a mark with a black fur dye for individual recognition (Armitage, 1962, 1974). Trapping effort varied somewhat over the 32 years but nearly all marmots in 5 colonies (River, Marmot Meadow, Picnic, Boulder, North Picnic) were captured each year. An additional colony was trapped annually beginning in 1976 (Cliff), and 4 other colonies were trapped when occupied. Nearly all marmots at 22 smaller habitat sites (satellites) were captured when the sites were occupied, but not all sites were trapped every year before 1983 . Trapping at satellite sites was more intensive during radio-tracking of marmots from 1983 through 1993 (Van Vuren, 1990; Van Vuren \& Armitage, 1994a, 1994b).

\section{Analysis}

Disappearance from the study area was considered to be equivalent to mortality because we did not always know if disappearance was due to death or dispersal. Marmots considered transients (i.e. trapped at a site, but did not become resident) were excluded. Of the 1860 marmots trapped, ages were known for 1532 marmots and these are the basis for this demography; data from 95 unknown age female marmots assumed to be 3 years old were used in a revision of this life table.

Demographic statistics were calculated from knownage marmots using Caughley's (1977: 91-93) Method 2 life-table approach where animals are sampled at regular (here yearly) intervals. This method makes no assumptions that the age distribution of a population is stable, and we detected fluctuations in natality and mortality that indicated variable relative age distributions. All life-table notations and calculations follow those of Krebs (1994: 168-195).

\section{Survivorship}

The number alive $\left(n_{\mathrm{x}}\right)$ in each age class $x$ was compiled at yearly intervals and the median survivorship was found using the Biomedical Data Processing (BMDP) software, program 1L (Dixon, 1988: 689). Survivorship of males and females was compared using the Breslow statistic of BMDP1L. This statistic is similar to the Kruskal-Wallis and Wilcoxon statistics but is not as sensitive to the tail of the survivorship curve when few individuals remain in the population (Dixon, 1988: 700). Survivorship $\left(l_{\mathrm{x}}\right)$, number dying $\left(d_{\mathrm{x}}\right)$, and death rate $\left(q_{\mathrm{x}}\right)$ for each age class were determined and used to calculate the life expectancy $\left(e_{\mathrm{x}}\right)$ for each class.

\section{Maternity}

Age of first reproduction was determined when the first litter of a female appeared above ground, and the mean age was calculated. We determined the proportion of adult females reproducing (weaned a litter), and calculated the mean, median, and modal litter size at emergence above ground by sex and with the sexes combined. Litter size and number of male young per litter were compared among age classes with a 1-way analysis of variance and Bonferroni and Tukey methods were used to identify significantly different means (SAS, 1990: 913). Where not normally distributed, litter size was compared among age classes with a Kruskal-Wallis test (Sokal \& Rohlf, 1995: 423). The mean number of female young per female $\left(b_{\mathrm{x}}\right)$ was calculated for each age class. The product, $l_{\mathrm{x}} b_{\mathrm{x}}$ was calculated for each age class and summed to find the net reproductive rate $\left(R_{\mathrm{o}}\right)$, and that was used to calculate the mean generation length $(G)$, the mean time for a female to replace herself with a female offspring. The innate capacity for increase $\left(r_{\mathrm{m}}\right)$ was approximated using $\log _{e}\left(R_{\mathrm{o}}\right) / G$, and this approximation was used to begin an iterative calculation using the Euler-Lotka equation to find the exact value for $\left(r_{\mathrm{m}}\right)$. The finite rate of increase $(\lambda)$ was calculated as $e^{r x}$. We chose to calculate reproductive value $\left(V_{\mathrm{x}}\right)$, the 
Table 1. Life-table statistics calculated for male yellow-bellied marmots from the East River Valley of Gunnison County, Colorado, that were studied from 1962 to 1993

\begin{tabular}{llllll}
\hline Age class & Number alive $n_{\mathrm{x}}$ & Surviorship $l_{\mathrm{x}}$ & Number dying $d_{\mathrm{x}}$ & Death rate $q_{\mathrm{x}}$ & Life expectancy \\
\hline 0 & 759 & 1.000 & 357 & 0.470 & 1.388 \\
1 & 402 & 0.530 & 282 & 0.702 & 1.177 \\
2 & 120 & 0.158 & 57 & 0.475 & 1.767 \\
3 & 63 & 0.083 & 27 & 0.429 & 1.913 \\
4 & 36 & 0.047 & 10 & 0.423 & 1.972 \\
5 & 26 & 0.034 & 11 & 0.467 & 1.539 \\
6 & 15 & 0.020 & 7 & 0.500 & 1.000 \\
7 & 8 & 0.011 & 3 & 0.750 & 0.500 \\
8 & 4 & 0.005 & 1 & 1.000 & 0.000 \\
9 & 1 & 0.000 & 3 & \\
\hline
\end{tabular}

number per age class of present and future expected female offspring, so that $V_{\mathrm{o}}=R_{\mathrm{o}}$ and is in animal units, rather than expressing it as a relative value of 1.0 for the zero age class (Fisher, 1958).

\section{Sex ratio and residency}

We determined the sex ratio for each age class from the life-table data and compared these ratios with the assumption of equality using a $G$ statistic (Sokal \& Rohlf, 1995: 697). To determine sources of residents we categorized each subadult (age 0 or 1 ) and adult male and female marmot each year as a resident at their natal site, here termed recruit, or as an immigrant. Some marmots were categorized as unknown (e.g. present when trapping was initiated, or not trapped in a given year). The frequencies of these categories were tabulated for all data.

\section{Adjustments to life table}

To determine the contribution of unknown-aged females to $R_{\mathrm{o}}$, we recalculated the life table after assuming that each unknown-aged marmot was 3-years old in the first year captured, which increased the sample size from 773 to 868 females. To further define the population we used the above assumption about unknown age classes, excluded individuals first captured before 1970 because there were fewer individuals of known age class, and used only data from the core 6 colonies and 22 satellite sites that were regularly trapped and then recalculated the life table based on 608 females.

\section{RESULTS}

\section{Survivorship}

Life-table statistics calculated for 759 males (Table 1) and 773 females (Table 2 ) revealed that females occurred in six more age classes than did males. Mortality occurred at an approximately constant rate (Fig. 1), and female survivorship was significantly greater overall than for males (Breslow statistic $=6.941$; d.f. $=1 ; P=0.0084$ ). Life expectancy at age class 0 was 1.39 years for males and 1.88 years for females and was greater for females at all ages (Tables $1 \& 2$ ). Median ( $\pm 1 \mathrm{SE}$ ) survivorship was $1.13 \pm 0.05$ years for males and $1.20 \pm 0.06$ years for females. We used the $q_{x}$ column for females aged $\geq 2$ years to calculate the rate of senescence as defined by Promislow (1991). The least squares analysis gave a slope of 0.006 , which did not differ significantly from 0 $(P=0.49)$. We also calculated the instantaneous mortality rate, which was plotted against age in years for female marmots up to age 9 years. The resultant curve was similar to the two-phase model of Sibly et al. (1997: fig. $2 b$ ), which was calculated from our earlier demography (Armitage \& Downhower, 1974). This model indicates different mortality rates between juveniles and adults, but does not reveal an age of senescence. Thus, neither analysis provided evidence for an increased rate of mortality with increased age. However, the failure of

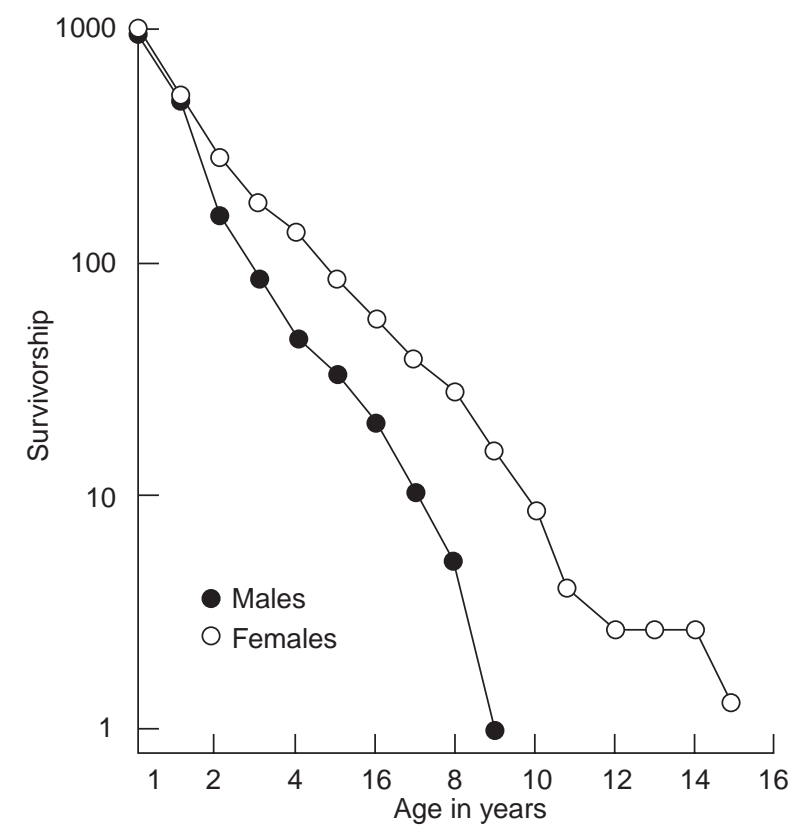

Fig. 1. Male and female survivorship curves from a population of yellow-bellied marmots Marmota flaviventris studied from 1962 to 1993, inclusive. See Tables 1 and 2 for sample sizes. 
Table 2. Life-table statistics calculated for female yellow-bellied marmots from the East River Valley of Gunnison County, Colorado, that were studied from 1962 to 1993

\begin{tabular}{|c|c|c|c|c|c|c|c|}
\hline $\begin{array}{l}\text { Age } \\
\text { class }\end{array}$ & $\begin{array}{l}\text { Number alive } \\
n_{\mathrm{x}}\end{array}$ & $\begin{array}{l}\text { Survivorship } \\
l_{\mathrm{x}}\end{array}$ & $\begin{array}{l}\text { Number dying } \\
d_{\mathrm{x}}\end{array}$ & $\begin{array}{l}\text { Death rate } \\
q_{\mathrm{x}}\end{array}$ & $\begin{array}{l}\text { Life expectancy } \\
e_{\mathrm{x}}\end{array}$ & $\begin{array}{l}\text { Number of female } \\
\text { young } b_{\mathrm{x}}\end{array}$ & $\begin{array}{l}\text { Reproductive } \\
\text { value } V_{\mathrm{x}}\end{array}$ \\
\hline 0 & 773 & 1.000 & 353 & 0.457 & 1.879 & 0.000 & 0.671 \\
\hline 1 & 420 & 0.543 & 212 & 0.505 & 2.036 & 0.000 & 1.236 \\
\hline 2 & 208 & 0.269 & 69 & 0.332 & 2.601 & 0.457 & 2.495 \\
\hline 3 & 139 & 0.180 & 33 & 0.237 & 2.644 & 0.734 & 3.05 \\
\hline 4 & 106 & 0.137 & 39 & 0.368 & 2.311 & 1.000 & 3.038 \\
\hline 5 & 67 & 0.087 & 23 & 0.343 & 2.366 & 1.122 & 3.223 \\
\hline 6 & 44 & 0.057 & 13 & 0.296 & 2.341 & 1.020 & 3.199 \\
\hline 7 & 31 & 0.040 & 9 & 0.290 & 2.113 & 1.093 & 3.096 \\
\hline 8 & 22 & 0.029 & 10 & 0.455 & 1.773 & 1.680 & 2.818 \\
\hline 9 & 12 & 0.016 & 5 & 0.417 & 1.833 & 1.336 & 2.086 \\
\hline 10 & 7 & 0.009 & 4 & 0.571 & 1.786 & 1.286 & 1.286 \\
\hline 11 & 3 & 0.004 & 1 & 0.333 & 2.500 & 0.000 & 0.000 \\
\hline 12 & 2 & 0.003 & 0 & 0.000 & 2.500 & 0.000 & 0.000 \\
\hline 13 & 2 & 0.003 & 0 & 0.000 & 1.500 & 0.000 & 0.000 \\
\hline 14 & 2 & 0.003 & 1 & 0.500 & 0.500 & 0.000 & 0.000 \\
\hline 15 & 1 & 0.001 & 1 & 1.000 & 0.000 & 0.000 & 0.000 \\
\hline \multicolumn{4}{|c|}{$R_{0}=0.6713$} & \multicolumn{2}{|c|}{$r_{\mathrm{m}}=-0.0851$} & $G=4.49$ & \\
\hline
\end{tabular}

females aged 10 years or older to reproduce suggests that reproductive senescence may occur.

\section{Maternity}

The mean age at first reproduction was $3.02 \pm 0.10$ years, the median was 3 years, the mode was 2 years, and the range was from 2 to 6 years for 119 females. No litters were produced by marmots $>10$ years old (Table 2). At first emergence above ground for 265 litters, the mean litter size was $4.1 \pm 0.1$ (Table 3 ), the median was 4 , and the modal number was 5 . The mean number of males and females was equal $\left(t_{264}=0.71, P=0.12\right)$, but the mode was 2 for male and 1 for female young. Mean litter size at first emergence above ground was smallest for the 2-year age class and greatest for the 9-year age class (Table 3), but there was no linear trend and no significant difference among reproductive age classes in litter size $\left(F_{8,256}=1.51 ; P=0.15\right)$ or number of female young $(H=9.89$; d.f. $=8 ; P=0.27)$. The number of male young differed significantly among age classes $\left(F_{8,256}=2.28 ; P=0.02\right)$, but the Bonferroni and Tukey methods identified no significant difference among means. We calculated the net reproductive rate $R_{\mathrm{O}}=0.6713$, the innate capacity for increase $r_{\mathrm{m}}=-$ 0.0851 , the finite rate of increase $\lambda=0.9184$, and the generation length $G=4.49$ years. Reproductive value $\left(V_{\mathrm{x}}\right)$ was relatively constant from ages 3 to 8 years and became zero beyond age 10 years (Table 2).

\section{Sex ratio and residency}

Sex ratio at first emergence above ground and at age 1 year did not differ from equality, but it was significantly female-biased from ages 2 to 9 years (Table 3); beyond age 9 years there were no surviving males. Most males and females $<2$ years old were trapped in their natal colony; at age 2 years twice as many females as males were trapped in their natal colonies. Most males disappeared by age 3 years and only four of 402 returned to become residents in their natal colony. By contrast 50 $70 \%$ of females became residents of their natal colony (Table 4).

\section{Adjusted life tables}

Recalculation of the life table that included treating 95 unknown age adult female marmots as 3-years-old in their first year of capture increased $R_{\mathrm{o}}$ from 0.6713 to 0.7995 and $r_{\mathrm{m}}$ from -0.0851 to $-0.0490(\lambda=0.9522)$. Recalculation of the life table with the unknown-age marmots and using data from the more limited, regularly trapped sample increased $R_{\mathrm{o}}$ to 0.8519 and $r_{\mathrm{m}}$ to $0.0339(\lambda=0.9667)$.

\section{DISCUSSION}

This demography of yellow-bellied marmots is for the metapopulation that exists on habitat patches that differ in population density and in habitat quality (Svendsen, 1974; Armitage, 1977, 1988) and where survivorship and reproduction vary among years within a habitat and within years among habitats (Armitage, 1988). Thus, the cohort-specific demography represents average conditions over a long time period. Factors responsible for this demography are described in the following discussion.

\section{Sources of mortality}

One major source of mortality was predation by coyotes Canis latrans, pine marten Martes americana, black bears 
Table 3. Age-specific sex ratios, mean ( $\pm \mathrm{SE}$ ) litter sizes, and proportion reproducing by age class in yellow-bellied marmots

\begin{tabular}{|c|c|c|c|c|c|c|}
\hline \multirow[b]{2}{*}{ Age class } & \multirow{2}{*}{$\begin{array}{l}\text { Sex ratio } \\
(\text { No. F:100 M) }\end{array}$} & \multirow[b]{2}{*}{$n$} & \multicolumn{3}{|c|}{ Litter size } & \multirow{2}{*}{$\begin{array}{l}\text { Percentage of } \\
\text { females reproducing }\end{array}$} \\
\hline & & & All & Male & Female & \\
\hline 0 & 102 & 0 & 0 & 0 & 0 & 0 \\
\hline 1 & 102 & 0 & 0 & 0 & 0 & 0 \\
\hline 2 & $173 * * *$ & 47 & $3.7 \pm 0.2$ & $1.8 \pm 0.3$ & $1.9 \pm 0.2$ & 22.6 \\
\hline 3 & $221 * * *$ & 52 & $4.0 \pm 0.2$ & $2.0 \pm 0.2$ & $2.0 \pm 0.2$ & 37.4 \\
\hline 4 & $294 * * *$ & 56 & $3.9 \pm 0.2$ & $2.0 \pm 0.1$ & $1.8 \pm 0.2$ & 52.8 \\
\hline 5 & $258 * * *$ & 42 & $4.5 \pm 0.2$ & $2.7 \pm 0.2$ & $1.8 \pm 0.2$ & 62.7 \\
\hline 6 & $293 * * *$ & 24 & $4.0 \pm 0.3$ & $2.2 \pm 0.3$ & $1.9 \pm 0.2$ & 54.5 \\
\hline 7 & $275^{* *}$ & 19 & $4.2 \pm 0.4$ & $1.8 \pm 0.2$ & $2.4 \pm 0.3$ & 61.3 \\
\hline 8 & $300^{*}$ & 14 & $4.7 \pm 0.4$ & $2.1 \pm 0.2$ & $2.6 \pm 0.3$ & 63.6 \\
\hline 9 & $700 *$ & 7 & $4.9 \pm 0.8$ & $2.6 \pm 0.5$ & $2.3 \pm 0.6$ & 58.3 \\
\hline 10 & all female & 4 & $4.0 \pm 0.9$ & $1.8 \pm 0.3$ & $2.3 \pm 0.8$ & 57.1 \\
\hline all & 130 & 265 & $4.1 \pm 0.1$ & $2.1 \pm 0.1$ & $2.0 \pm 0.1$ & \\
\hline
\end{tabular}

$* P<0.05, G>4.1 ; * * P<0.01, G>6.7 ; * * * P<0.0001, G>14.8$

Table 4. Sources of residents into the study population. A recruit was a resident at its natal site and an immigrant was born elsewhere

\begin{tabular}{|c|c|c|c|c|c|c|}
\hline \multicolumn{7}{|c|}{ Percentage of residents } \\
\hline \multirow[b]{2}{*}{ Age class } & \multicolumn{2}{|c|}{ Recruit } & \multicolumn{2}{|c|}{ Immigrant } & \multicolumn{2}{|c|}{ Unknown } \\
\hline & Male & Female & Male & Female & Male & Female \\
\hline 0 & 98.1 & 97.6 & & 0.1 & 1.9 & 2.3 \\
\hline 1 & 84.9 & 78.8 & 8.3 & 12.3 & 6.3 & 9.1 \\
\hline 2 & 35.8 & 66.0 & 53.2 & 16.7 & 11.1 & 17.2 \\
\hline 3 & 3.3 & 68.8 & 80.0 & 22.0 & 16.7 & 9.2 \\
\hline 4 & 2.7 & 63.6 & 73.0 & 28.0 & 24.3 & 8.4 \\
\hline 5 & 11.5 & 59.4 & 84.6 & 31.9 & 3.8 & 7.7 \\
\hline 6 & 12.5 & 57.8 & 81.3 & 31.1 & 6.3 & 11.1 \\
\hline 7 & 11.1 & 46.9 & 77.8 & 40.6 & 11.1 & 12.5 \\
\hline 8 & & 60.9 & 100.0 & 30.4 & & 8.6 \\
\hline 9 & & 50.0 & 100.0 & 25.0 & & 25.0 \\
\hline$\geq 10$ & & 33.0 & & 33.0 & & 33.0 \\
\hline
\end{tabular}

Ursus americana, badgers Taxidea taxus, golden eagles Aquila chrysaetos and long-tailed weasels Mustela frenata (Andersen \& Johns, 1977; Armitage, 1982; Van Vuren, 1990; Van Vuren \& Armitage, 1994a). During a radiotelemetric study, all mortality during the active season was attributed to predation, which was especially high on dispersing marmots (Van Vuren \& Armitage, 1994a).

Unsuccessful hibernation was a second major source of mortality. Most hibernation-related mortality appeared to result from a complex interaction between physiological condition and length of winter (Armitage \& Downhower, 1974; Schwartz \& Armitage, in press $b$ ). Young and adults of low mass at entry into hibernation were unlikely to survive (Armitage et al., 1976; Armitage, 1994; Lenihan \& Van Vuren, 1996). Survival of young and of adults was greater when winter terminated early (Armitage \& Downhower, 1974). Low summer rainfall was associated with poor mass increase before hibernation and low overwinter survival of juvenile yellow-bellied marmots (Lenihan \& Van Vuren, 1996).
Although we observed a few males with wounds (Van Vuren \& Armitage, 1994a), there was little fighting during the mating season, and intraspecific fighting was not a direct source of mortality in marmots. In contrast, males of some species of ground-dwelling sciurids fight intensely during the mating season; hence, mortality increased relative to that of females (Sherman \& Morton, 1984; Michener \& Locklear, 1990). Territorial defence involved mainly displays and chases (Armitage, 1974). Conflict among competing males may be stressful; we recorded laboratory deaths of several males that initially seemed normal but subsequently showed signs of stress and died within a few hours. Each dead male was involved in agonistic interactions with other males just before capture (Armitage, 1974). We have not observed stress-related mortality with adult females. Stress-related death may contribute to the higher rates of male mortality beyond age 2 years. Minor sources of mortality (about $1 \%$ ) included shooting, trap deaths, and other accidents. 
Table 5. Survivorship to yearling age and adult sex ratios of ground-dwelling scuirids. + , indicates those species with decreased male survivorship

\begin{tabular}{|c|c|c|c|c|c|c|}
\hline & \multicolumn{3}{|c|}{ Percent surviving to age 1 year } & \multirow[b]{2}{*}{$\begin{array}{l}\text { Adult sex ratio } \\
\text { (male:females) }\end{array}$} & \multirow[b]{2}{*}{$\begin{array}{l}\text { Decreased male } \\
\text { survivorship }\end{array}$} & \multirow[b]{2}{*}{ Reference } \\
\hline & Male & Female & $\begin{array}{l}\text { Sexes } \\
\text { combined }\end{array}$ & & & \\
\hline \multicolumn{7}{|l|}{ Relatively asocial: } \\
\hline S. armatus & \multicolumn{2}{|c|}{ Male $>$ Female } & \multirow[t]{2}{*}{$29-41$} & $1: 1.74$ & & \multirow{2}{*}{$\begin{array}{l}\text { Slade \& Balph (1974) } \\
\text { Sherman \& Morton (1984) }\end{array}$} \\
\hline S. beldingi & 31 & 35 & & $\begin{array}{l}1: 1 \text { ( } 1-2 \text { yr age class }) \\
1: 2.7 \text { ( } 3-4 \text { yr age class })\end{array}$ & + & \\
\hline S. beecheyi & 31 & 41 & & $1: 1.23$ & & Fitch (1948) \\
\hline S. columbianus & 35 & 40 & & $1: 1.2-2.3$ & + & Boag \& Murie (1981) \\
\hline S. elegans & & & 19 & $1: 1.78$ & & $\begin{array}{l}\text { Pfeiffer (1982), Zegers \& } \\
\quad \text { Williams (1977) }\end{array}$ \\
\hline S. lateralis & & & 18 & $1: 2.6$ & & Bronson (1979) \\
\hline S. parryii & 16 & 42 & & $1: 1.23$ & & McLean (1982) \\
\hline S. richardsonii & 12 & 46 & & $1: 3.6-5$ & + & $\begin{array}{l}\text { Michener \& Locklear (1990); } \\
\text { Michener (1989 }\end{array}$ \\
\hline S. tridecemlineatus & 3 & 15 & & $1: 1.9$ & + & McCarley (1966) \\
\hline C. leucurus & 8 & 27 & & $1: 1.88-1.95$ & & Tileston \& Lechleitner (1966) \\
\hline M. monax & & & 24 & $1: 1$ & & $\begin{array}{l}\text { Davis, Christian \& Bronson } \\
\quad(1964) \\
\text { Snyder }(1962)\end{array}$ \\
\hline \multicolumn{7}{|r|}{ (1) } \\
\hline C. gunnisoni & 49 & 42 & & $\begin{array}{l}1: 1.93 \text { (all adults) } \\
1: 2.1 \text { (harem) }\end{array}$ & & Rayor (1985), (1988) \\
\hline C. ludovicianus & & & 50 & $1: 1.48$ & & King (1955) \\
\hline & 47 & 54 & & $1: 2.2$ & + & Hoogland (1995) \\
\hline M. flaviventris & 53 & 54 & & $1: 2.3$ & + & This study \\
\hline M. olympus & & & $52-55$ & $1: 1.5$ & + & Barash (1973) \\
\hline M. caligata & & & & $1: 1.8$ & & Barash $(1974 b)$ \\
\hline
\end{tabular}

\section{Survivorship patterns and comparisons}

Marmots had a Type II survivorship curve where approximately constant proportions of individuals survived through each age class (Krebs, 1994: 171). The principal causes of mortality affected each age class equally. The first two summers of life (ages 0 and 1) were characterized as a period of maturation associated with high mortality. Survivorship beyond age 1 year in three marmot species of higher social complexity (Blumstein \& Armitage, 1997) is significantly greater than that of yellow-bellied marmots (Blumstein, Daniel $\&$ Arnold, in press); thus, the survivorship curves of the more socially complex species are less steep than that of the yellow-bellied marmot. The higher survivorship and greater longevity of yellow-bellied marmot females than of males is variable among animals and has rarely been examined to an advanced age (D. W. E. Smith, 1989).

The survivorship of yellow-bellied marmots may be compared to survivorship among the ground-dwelling sciurids, which were divided into two groups, relatively asocial (grades 1 to 3 ) and social (grades 4 and 5, Armitage, 1981; Michener, 1983). Among the relatively asocial species, survivorship to age 1 year ranged from 3\% in male thirteen-lined ground squirrels Spermophilus tridecemlineatus to $46 \%$ in female Richardson's ground squirrels Spermophilus richardsonii (Table 5). Female survivorship was greater than male survivorship and may be as much as five times greater (e g. thirteen-lined ground squirrels). By contrast, survivorship in the first year among the social species always was $>42 \%$ and differed little between sexes (Table 5). The difference in juvenile survival between social and asocial species likely results from the difference in the timing of dispersal. Dispersal is delayed to the second summer of life or later in the social species (also in Columbian ground squirrel Spermophilus columbianus, which has higher survivorship than other relatively asocial species), thus delaying the high mortality associated with dispersal (Armitage, 1981). The higher survivorship of young of the social species may increase the probability of producing reproductive descendents than would be likely if their young dispersed at a younger age and smaller size (Armitage, 1992).

Female philopatry characterizes both relatively asocial and social sciurids (Armitage, 1981; Michener, 1983). From ages 1 to 2 years in yellow-bellied marmots, the dispersal of most males and the philopatry of the majority of females (Table 4) differentially affected the survivorship curve; female survivorship from age 1 to 2 years remained at about $50 \%$, whereas male survivorship decreased to $30 \%$. In contrast, delayed dispersal to the third summer in the Vancouver marmot Marmota vancouverensis and Olympic marmot Marmota olympus accounts for the higher survivorship in these socially more complex species (Armitage, 1996; Blumstein \& Armitage, 1997). Dispersing males usually sustained greater mortality than philopatric females (e.g. Van Vuren \& Armitage, 1994a). This decrease in 
male survivorship occurs in other polygynous grounddwelling squirrels (Table 5).

From age 2 years, most females are philopatric (Table 4) and form female kin groups (Armitage, 1987b). The rate of survivorship of yellow-bellied marmots, although lower for males, was constant until age 9 years in males and age 11 years in females, beyond which few survived. The higher rate of mortality of 2-year-old males than that of 2-year-old females (Tables $1 \& 2$ ) apparently is a consequence of males still moving widely seeking residency with females (Van Vuren, 1990). This sex-bias in survival increases the difference in the survivorship curves of males and females (Fig. 1). Similarly, a progressively female-biased sex ratio occurs in all the ground-dwelling sciurids except for the asocial woodchuck Marmota monax (Table 5; also see Boag and Murie, 1981: table 10).

\section{Maternity patterns and comparisons}

First reproduction in yellow-bellied marmots occurred in $22.6 \%$ of 2-year-olds, but for the remainder was delayed to as late as 6 years. Although reproduction was inhibited by dominant females (Armitage, 1986, 1989), delayed reproduction may be influenced by energy constraints of the habitat. In the genus Marmota reproduction was reported at age 1 year in woodchucks, but was delayed in all other species of marmots by limited time and energy available during the shorter growing seasons in their habitats (Barash, 1974b; Armitage, 1996; Bibikow, 1996; Armitage \& Blumstein, in press). Yearlings of ground-dwelling sciurids do not reproduce, or reproduce at much lower rates, than older animals; examples include woodchucks (Snyder, 1962), Belding's ground squirrels Spermophilus beldingi (Sherman \& Morton, 1984), Columbian ground squirrels (Festa-Bianchet, 1981; Dobson \& Murie, 1987), Uinta ground squirrels Spermophilus armatus (Slade \& Balph, 1974), thirteen-lined ground squirrels (McCarley, 1966), golden-mantled ground squirrels Spermophilus lateralis (Bronson, 1979), black-tailed prairie dogs (King, 1955; R. E. Smith, 1958; Hoogland, 1981, 1995), Gunnison's prairie dogs Cynomys gunnisoni (Rayor, 1985), Olympic marmots (Barash, 1973) and hoary marmots Marmota caligata (Barash, 1974a). Increased energy availability increased the frequency of reproduction in yearling black-tailed prairie dogs (Koford, 1958) and Gunnison's prairie dog yearlings bred only when food was more abundant (Rayor, 1985). More yearling female Columbian ground squirrels reproduced on food-supplemented sites than on non-supplemented sites and in low-elevation habitats with a longer growing season (Dobson \& Kjelgaard, 1985; Dobson, Zammuto \& Murie, 1986; Dobson \& Murie, 1987). Among populations of golden-mantled ground squirrels, age of first reproduction was delayed at higher elevations (Bronson, 1979). Energy constraints may delay age of first reproduction in yellow-bellied marmots but, if reproduction occurs, litter size does not seem so constrained.
Mean litter size was equal for all reproductive age classes of yellow-bellied marmots. At 4.1, mean litter size was similar to those of other Marmota, but was in the lower size-range of the distribution for all grounddwelling squirrels (Armitage, 1981). This result contrasted with the pattern in Belding's ground squirrel where litter size increased steadily during years 1-4 and decreased thereafter (Sherman \& Morton, 1984). Litter sizes of yearling females was smaller than that of older females in Columbian ground squirrels (Festa-Bianchet, 1981; Festa-Bianchet \& King, 1991), Uinta ground squirrels (Slade \& Balph, 1974), Wyoming ground squirrels Spermophilus elegans (Pfeifer, 1982), thirteenlined ground squirrels (McCarley, 1966), goldenmantled ground squirrels (Bronson, 1979), Richardson's ground squirrels (Michener, 1980), woodchucks (Snyder \& Christian, 1960), and black-tailed prairie dogs (Koford, 1958; Hoogland, 1995). In yellow-bellied marmots the number of female young per litter at first emergence above ground was equal for all age classes. However, young females living in particular social groups sometimes produced female-biased litters (Armitage, 1987a). Because the overall sex ratio at first emergence was $1: 1$, some females at some sites must have produced more sons than daughters to balance the female-biased litters. However, no significant malebiased litters occurred among the age classes. Energy constraints may have precluded an age-specific peak in litter size and contributed to a low net reproductive rate.

The net reproductive rate and $\lambda$ were $<1.0$ and the intrinsic rate of increase was negative, which suggested a population that was continually declining to extinction. Although numbers of marmots in our study area fluctuated several times from as low as $58-76$ and to as high as 162-184 in a year, the population did not decline and the core population seemed stable as densities fluctuated around an average (Armitage, 1991). Low net reproductive rates of marmots differed from those of the Uinta ground squirrel, which ranged from 0.89 to 1.87 in different habitats and before and after population reductions (Slade \& Balph, 1974), and from that of Belding's ground squirrel, which was 1.37 (Sherman \& Morton, 1984). Sherman \& Morton (1984) reported that the Belding's ground squirrel population was stable despite the high $R_{\mathrm{o}}$. Because marmots dispersed from the study area and sampling effort at the non-colonial sites varied over the duration of our study, net reproductive rate and the intrinsic rate of increase may have been underestimated. Thus, the addition of immigrants of uncertain age to the analysis and the exclusion of individuals that were not regularly monitored produced statistics nearer to that of a self-sustaining population.

The relative equality of age-specific reproductive values of marmots from 3 to 8 years was surprising; like the survivorship curve, it was a spatial and temporal average of individual marmots. With a generation time of 4.49 years, 2.4 times the life expectancy of a female at birth, yellow-bellied marmots must have a long-lived life-history strategy because only half of the adult females reproduce each year (Armitage, 1984, 1991), 
and no age-specific peak of reproductive effort was possible for all individuals. The Type II survivorship curves of yellow-bellied marmots also occurred in Belding's ground squirrel (Sherman \& Morton, 1984); however, the curve for reproductive value in yellowbellied marmots was nearly flat from 3 to 8 years of age, and in Belding's ground squirrel it was near its peak from 2 to 4 years, then declined rapidly, and was then again flat from 5 to 7 years (Sherman \& Morton, 1984: fig. 4). No explanation for the large decrease in reproductive value between ages 4 and 5 years was available, and this decrease represented the major difference between the reproductive value curves of the two species. In effect, the two relatively flat areas of the Belding's ground squirrel curve were represented as one broad flat area in the yellow-bellied marmot curve. Females of both species had a similar reproductive lifespan: ages 1-9 years in Belding's ground squirrel and ages 2-10 years in the yellow-bellied marmot. For M. bobac, reproductive value increased to a peak at age 5 years and declined steeply after age 7 years (Shubin, 1991). Similarly, a 2-year peak and subsequent decline in reproductive value could be calculated from Hoogland's (1995) data on the black-tailed prairie dog. The matrilineal social organization of yellow-bellied marmots may provide a more stable access to available resources and enhance survivorship until years when resources are sufficient for reproduction (Armitage, 1986, 1988, 1989, 1996; Van Vuren, 1990). The average effect of lack of annual reproduction across the study area where resources are not homogeneously distributed is a relatively flat curve of reproductive values.

\section{Sex ratio and residency}

In yellow-bellied marmots, the increasingly femalebiased sex ratio and residency pattern are a consequence of male dispersal and female philopatry and the increased mortality of dispersers (Van Vuren \& Armitage, 1994a). Male dispersal is best explained as a result of mate competition; yearling males were subordinate to adult males and were treated agonistically until they dispersed (Armitage, 1974; Downhower \& Armitage, 1981; Armitage \& Johns, 1982). Some adult males subsequently occupied a habitat site with female residents and defended the site (Armitage, 1986, 1991). Because they are uncommon, adult males contribute little to population fluctuation in any habitat patch (Armitage, 1991).

Population fluctuations and long-term stability were a consequence of the variation in numbers of females (Armitage, 1986, 1991). The population increased primarily when adult females recruited daughters to form matrilines that grew in size and occupied all available burrow and foraging areas (Armitage, 1973, 1975, 1988, 1989, 1991, 1996). Matrilineal organization occurred at every suitable habitat patch trapped regularly for at least 10 years. When matrilines occupied all of a habitat patch, immigration did not occur (Armitage, 1984,
1991). Immigration was rare when recruitment occurred and was weakly, negatively related to density (Armitage, 1988); twice as many females became residents as recruits than as immigrants. Immigration occurred when death created a vacancy and an immigrant occupied that space; displacement of residents by immigrants almost never occurred (Armitage, 1984, 1991). Thus, the observed patterns of sex ratio and residencies were mostly a function of the social system.

\section{Comparison with the 1974 study}

The previous demography of this population, based on 460 animals captured from 1962 to 1972 (Armitage \& Downhower, 1974), provides interesting contrasts with this 32-year study. Recruitment of males and females to their natal sites was similar in both studies, but our study reports greater proportions of females in the older age classes at their natal sites. In 1974, the oldest known females were aged 7 years; now we report that females reproduce up to age 10 years, two females reached age 14 years, and one female attained age 15 years. In the 1974 study, one male had become resident in his natal colony; only three additional instances have occurred in the subsequent 21 years, thus affirming the rarity of male recruitment. Sex ratio at first emergence above ground did not differ between the two studies, and the difference in mean litter size $(4.2 \pm 0.2$ in $1974,4.1 \pm 0.1$ this study) was biologically insignificant. However, the more extensive time period produced a major difference in the estimated adult sex ratio, 1:1.3 in 1974 vs 1:2.3 in this study. After 1974, trapping at smaller sites was more extensive and sites typically were inhabited by females; also, at times a single male excluded other males from territories previously inhabited by two or three males. Comparable $R_{\mathrm{o}}$ values were 0.8098 in 1974 and 0.8519 in this study. In the 1974 study, predation was considered minimal and little information on the fates of dispersers was available. Now more information is available on the fates of dispersers, and high mortality from predation has been documented (Van Vuren, 1990). Thus, we could construct a life table for males, which was not possible in the earlier study. Differences between the two studies emphasize the importance of long-term studies.

This study makes clear that the polygynous mating system and demography form a positive feedback system. Dispersal of yearling males because of potential mate competition increases male mortality relative to that of the more philopatric females. Higher male mortality causes the female-biased adult sex ratio that produces polygynous mating, which, in turn, promotes dispersal of juvenile males.

Briefly, this analysis of demography of the yellowbellied marmot emphasizes the relationship between demography and the mating system, demonstrates that males and females have different patterns of survivorship and that females have greater longevity than males, indicates that senescence does not occur, and that there is no age-specific peak in reproduction. 


\section{Acknowledgemnents}

This research was conducted at the Rocky Mountain Biological Laboratory, Gunnison County, Colorado and supported by National Science Foundation Grants G16354, GB-1980, GB-6123, GB-8526, GB-32494, BMS74-21193, DEB78-07327, BSR-8121231, BSR8614690, and BSR-9006772 and by grants from The University of Kansas General Research Fund to K. B. Armitage, by Faculty Research Grants from the University of California, Davis, to D. Van Vuren, and by a sabbatical leave from the University of Northern Iowa to O. A. Schwartz. We thank J. L. Hoogland, J. O. Murie, F. S. Dobson, W. J. King, and an anonymous reviewer for many helpful comments, and the numerous graduate students, trappers, and field assistants whose dedicated efforts made possible the collection of the demographic data. Sharon Hagen prepared the figure and Sharon Lee Hopkins typed the manuscript.

\section{REFERENCES}

Andersen, D. C. \& Johns, D. W. (1977). Predation by badger on yellow-bellied marmot in Colorado. Southwest. Nat. 22: 283284.

Armitage, K. B. (1962). Social behaviour of a colony of the yellow-bellied marmot (Marmota flaviventris). Anim. Behav. 10: 319-331.

Armitage, K. B. (1973). Population changes and social behavior following colonization by the yellow-bellied marmot. $J$. Mammal. 54: 842-854.

Armitage, K. B. (1974). Male behaviour and territoriality in the yellow-bellied marmot. J. Zool. (Lond.) 172: 233-265.

Armitage, K. B. (1975). Social behavior and population dynamics of marmots. Oikos 26: 341-354.

Armitage, K. B. (1977). Social variety in the yellow-bellied marmot: a population-behavioural system. Anim. Behav. 25: 585-593.

Armitage, K. B. (1981). Sociality as a life-history tactic of groundsquirrels. Oecologia 48: 36-49.

Armitage, K. B. (1982). Marmots and coyotes: behavior of prey and predator. J. Mammal. 63: 503-505.

Armitage, K. B. (1984). Recruitment in yellow-bellied marmot populations: kinship, philopatry, and individual variability. In The biology of ground-dwelling squirrels: 377-403. Murie, J. O. \& Michener, G. R. (Eds). Lincoln: University of Nebraska Press.

Armitage, K. B. (1986). Marmot polygyny revisited: determinants of male and female reproductive strategies. In Ecological aspects of social evolution: 303-331. Rubenstein, D. I. \& Wrangham, R. W. (Eds). Princeton: Princeton University Press.

Armitage, K. B. (1987a). Do female yellow-bellied marmots adjust the sex ratios of their offspring? Am. Nat. 129: 501-519.

Armitage, K. B. (1987b). Social dynamics of mammals: reproductive success, kinship and individual fitness. Trends Ecol. Evol. 2: 279-284.

Armitage, K. B. (1988). Resources and social organization of ground-dwelling squirrels. In The ecology of social behavior: 131-155. Slobodchikoff, C. N. (Ed.). San Diego: Academic Press.

Armitage, K. B. (1989). The function of kin discrimination. Ethol. Ecol. Evol. 1: 111-121.

Armitage, K. B. (1991). Social and population dynamics of yellow-bellied marmots: results from long-term research. Annu. Rev. Ecol. Syst. 22: 379-407.
Armitage, K. B. (1992). Social organization and fitness strategies of marmots. In First International Symposium on alpine marmot: 89-94.

Armitage, K. B. (1994). Unusual mortality in a yellow-bellied marmot population. In Actual problems of marmots investigation: 5-13. Rumiantsev, V. (Ed.). Moscow: ABF Publishing House. Bassano, B., Durio, P., Gallo Oris, U., Macchi, E. (Eds.), Torino.

Armitage, K. B. (1996). Social dynamics, kinship, and population dynamics of marmots. In Biodiversity in marmots: 113-128. LeBerre, M., Ramousse, R., LeGuelte, L. (Eds). Moscow/ Lyon: International Marmots Network.

Armitage, K. B. \& Blumstein, D. T. (In press). Body-mass diversity in marmots. Proceedings of the 3rd International Marmot Conference, Cheboksary, Russia.

Armitage, K. B. \& Downhower, J. F. (1974). Demography of yellow-bellied marmots. Ecology 55: 1233-1245.

Armitage, K. B., Downhower, J. F. \& Svendsen, G. E. (1976). Seasonal changes in weights of marmots. Am. Midl. Nat. 96: $36-51$.

Armitage, K. B. \& Johns, D. W. (1982). Kinship, reproductive strategies and social dynamics of yellow-bellied marmots. Behav. Ecol. Sociobiol. 11: 55-63.

Barash, D. P. (1973). The social biology of the Olympic marmot. An. Behav. Monogr. 6: 173-245.

Barash, D. P. (1974a). The social behaviour of the hoary marmot (Marmota caligata). Anim. Behav. 22: 256-261.

Barash, D. P. (1974b). The evolution of marmot societies: a general theory. Science 185: 415-420.

Bibikow, D. (1996). Die Murmeltiere der Welt. Magdeburg: Westarp Wissenschaften.

Blumstein, D. T. \& Armitage, K. B. (1997). Does sociality drive the evolution of communicative complexity? A comparative test with ground-dwelling sciurid alarm calls. Am. Nat. 150: 179-200.

Blumstein, D. T., Daniel, J. C. \& Arnold, W. (In press). Survivorship of golden marmots (Marmota caudata aurea) in Pakistan. Proceedings of the 3rd. International Marmot Conference, Cheboksary, Russia.

Boag, D. A. \& Murie, J. O. (1981). Population ecology of Columbian ground squirrels in southwestern Alberta. Can. J. Zool. 59: 2230-2240.

Bronson, M. T. (1979). Altitudinal variation in the life history of the golden-mantled ground squirrel (Spermophilus lateralis). Ecology 60: 272-279.

Caughley, G. (1977). Analysis of vertebrate populations. New York: John Wiley.

Davis, D. E., Christian, J. J. \& Bronson, F. (1964). Effect of exploitation on birth, mortality, and movement rates in a woodchuck population. J. Wildl. Manage. 28: 1-9.

Dixon, W. J. (1988). BMDP statistical software manual. Berkeley: University of California Press.

Dobson, F. S. \& Kjelgaard, J. D. (1985). The influence of food resources on population dynamics in Columbian ground squirrels. Can. J. Zool. 63: 2095-2104.

Dobson, F. S. \& Murie, J. O. (1987). Interpretation of intraspecific life history patterns: Evidence from Columbian ground squirrels. Am. Nat. 129: 382-397.

Dobson, F. S., Zammuto, R. M. \& Murie, J. O. (1986). A comparison of methods for studying life history in Columbian ground squirrels. J. Mammal. 67: 154-158.

Downhower, J. F. \& Armitage, K. B. (1981). Dispersal of yearling yellow-bellied marmots (Marmota flaviventris). Anim. Behav. 29: $1064-1069$.

Festa-Bianchet, M. (1981). Reproduction in yearling female Columbian ground squirrels (Spermophilus columbianus). Can. J. Zool. 59: 1032-1035.

Festa-Bianchet, M. \& King, W. J. (1991). Effects of litter size and population dynamics on juvenile and maternal survival in Columbian ground squirrels. J. Anim. Ecol. 60: 1077-1090. 
Fisher, R. A. (1958). The genetical theory of natural selection. 2nd edn. New York: Dover.

Fitch, H. S. (1948). Ecology of the California ground squirrel on grazing lands. Am. Midl. Nat. 39: 513-596.

Hoogland, J. L. (1981). Nepotism and cooperative breeding in the black-tailed prairie dog (Sciuridae: Cynomys ludovicianus). In Natural selection and social behavior: 283-310. Alexander, R. D. \& Tinkle, D. W. (Eds). New York: Chiron Press.

Hoogland, J. L. (1995). The black-tailed prairie dog: social life of a burrowing mammal. Chicago: University of Chicago Press.

Kilgore, D. L., Jr. \& Armitage, K. B. (1978). Energetics of yellowbellied marmot populations. Ecology 59: 78-88.

King, J. A. (1955). Social behavior, social organization, and population dynamics in a black-tailed prairiedog town in the Black Hills of South Dakota. Contr. Lab. Vert. Biol. Univ Mich. 67: 1-123.

Koford, C. B. (1958). Prairie dogs, whitefaces and blue grama. Wildl. Monogr. 3: 1-78.

Krebs, C. J. (1994). Ecology. The experimental analysis of distribution and abundance. 4th. edition. New York: Harper and Row.

Langenheim, J. H. (1962). Vegetation and environmental patterns in the Crested Butte Area, Gunnison County, Colorado. Ecol. Monogr. 32: 249-285.

Lenihan, C. \& Van Vuren, D. (1996). Growth and survival of juvenile yellow-bellied marmots (Marmota flaviventris). Can. J. Zool. 74: 297-302.

McCarley, H. (1966). Annual cycle, population dynamics, and adaptive behavior of Citellus tridecemlineatus. J. Mammal. 47: 294-316.

McLean, I. G. (1982). The association of female kin in the Arctic ground squirrel Spermophilus parryii. Behav. Ecol. Sociobiol. 10: 91-99.

Michener, G. R. (1980). Differential reproduction among female Richardson's ground squirrels and its relation to sex ratio. Behav. Ecol. Sociobiol. 7: 173-178.

Michener, G. R. (1983). Kin identification, matriarchies, and the evolution of sociality in ground-dwelling sciurids. In Advances in the study of mammalian behavior: 528-572. Eisenberg, J. F. \& Kleiman, D. G. (Eds). Special Publication, The American Society of Mammalogists.

Michener, G. R. (1989). Sexual differences in interyear survival and life-span of Richardson's ground squirrel. Can. J. Zool. 67: 1827-1831.

Michener, G. R. \& Locklear, L. (1990). Differential costs of reproductive effort for male and female Richardson's ground squirrels. Ecology 71: 855-868.

Pfeifer, S. R. (1982). Variability in reproductive output and success of Spermophilus elegans ground squirrels. J. Mammal. 63: $284-289$.

Promislow, D. E. L. (1991). Senescence in natural populations of mammals: a comparative study. Evolution 45: 1869-1887.

Rayor, L. S. (1985). Effects of habitat quality on growth, age at first reproduction, and dispersal in Gunnison's prairie dogs (Cynomys gunnisoni). Can. J. Zool. 63: 2835-2840.

Rayor, L. S. (1988). Social organization and space-use in Gunnison's prairie dog. Behav. Ecol. Sociobiol. 22: 69-78.
SAS (1990). STAT user's guide. Version 6. 3rd edn. North Carolina: SAS Institute.

Schwartz, O. A. \& Armitage, K. B. (In press a). Empirical considerations on the stable age distribution. Oecologia Montana.

Schwartz, O. A. \& Armitage, K. B. (In press b). Correlations between weather factors and life-history traits of yellow-bellied marmots. Proceedings of the 3rd International Marmot Conference, Cheboksary, Russia.

Sherman, P. W. \& Morton, M. L. (1984). Demography of Belding's ground squirrels. Ecology 65: 1617-1628.

Shubin, V. I. (1991). Population structure and bobac reproduction in the northern part of Kazakh Melkosopotchnik (= low hill area). In Population structure of the marmot: 98-117. Bibikow, D. I., Nickolski, A. A., Rumiantzev, V. Ju. \& Seredneva, T. A (Eds). Moscow: USSR Theriological Society.

Sibly, R. M., Collett, D., Promislow, D. E. L., Peacock, D. J. \& Harvey, P. H. (1997). Mortality rates of mammals. J. Zool. (Lond.) 243: 1-12.

Slade, N. A. \& Balph, D. F. (1974). Population ecology of Uinta ground squirrels. Ecology 55: 989-1003.

Smith, D. W. E. (1989). Is greater female longevity a general finding among animals? Biol. Rev. 64: 1-12.

Smith, R. E. (1958). Natural history of the prairie dog in Kansas. Univ. Kan. Mus. Nat. Hist. Misc. Pub. 16: 1-36.

Snyder, R. L. (1962). Reproductive performance of a population of woodchucks after a change in sex ratio. Ecology 43 $506-515$.

Snyder, R. L. \& Christian, J. J. (1960). Reproductive cycle and litter size of the woodchuck. Ecology 41: 647-656.

Sokal, R. R. \& Rohlf, F. J. (1995). Biometry. The principles and practice of statistics in biological research. 3rd edn. New York: W. H. Freeman.

Stearns, S. C. (1992). The evolution of life histories. New York: Oxford University Press.

Svendsen, G. E. (1974). Behavioral and environmental factors in the spatial distribution and population dynamics of a yellowbellied marmot population. Ecology 55: 760-771.

Tileston, J. V. \& Lechleitner, R. R. (1966). Some comparisons of the black-tailed and white-tailed prairie dogs in North-Central Colorado. Am. Midl. Nat. 75: 292-316.

Van Horne, B., Olson, G. S., Schooley, R. L., Corn, J. G., \& Burnham, K. P. (1997). Effects of drought and prolonged winter on Townsend's ground squirrel demography in shrubsteppe habitats. Ecol. Monogr. 67: 295-315.

Van Vuren, D. (1990). Dispersal of yellow-bellied marmots. PhD dissertation, University of Kansas, Lawrence.

Van Vuren, D. \& Armitage, K. B. (1994a). Survival of dispersing and philopatric yellow-bellied marmots: what is the cost of dispersal? Oikos 69: 179-181.

Van Vuren, D. \& Armitage, K. B. (1994b). Reproductive success of colonial and noncolonial female yellow-bellied marmots (Marmota flaviventris). J. Mammal. 75: 950-955.

Zegers, D. A. \& Williams, O. (1977). Seasonal cycles of body weight and lipids in Richardson's ground squirrel, Spermophilus richardsonii elegans. Acta Theriol. 22: 380-383. 